\title{
Effectiveness of Wireless Streaming on Telephone Conversation in Users of Hearing Aids
}

\author{
Young Sang Cho ${ }^{1,2}$, Soo Jin Kang ${ }^{2}$, Ji Hyun Lim³, Si Hyung Kang ${ }^{4}$, \\ Ji Won Seo ${ }^{4}$, Il Joon Moon ${ }^{1,2}$, and Sung Hwa Hong ${ }^{2,4}$ (i) \\ ${ }^{1}$ Department of Otorhinolaryngology-Head and Neck Surgery, ${ }^{2}$ Hearing Research Laboratory, ${ }^{3}$ Center for Clinical Epidemiology, \\ Sungkyunkwan University School of Medicine, Samsung Medical Center, Seoul; and \\ ${ }^{4}$ Department of Otorhinolaryngology-Head and Neck Surgery, Sungkyunkwan University School of Medicine, Samsung Changwon \\ Hospital, Changwon, Korea
}

\author{
전화 통화 시 보청기 무선 통신 기술의 유효성 \\ 조영상 $^{1,2} \cdot$ 강수진 $^{2} \cdot$ 임지현 ${ }^{3} \cdot$ 강시형 $^{4} \cdot$ 서지원 $^{4} \cdot$ 문일준 $^{1,2} \cdot$ 홍성화 ${ }^{2,4}$ \\ 성균관대학교 의과대학 삼성서울병원 이비인후과학교실, ${ }^{1}$ 청각연구실, ${ }^{2}$ 임상역학센터, \\ 성균관대학교 의과대학 삼성창원병원 이비인후과학교실 ${ }^{4}$
}

\author{
Received July 22, 2019 \\ Revised August 11, 2019 \\ Accepted August 26, 2019 \\ Address for correspondence \\ Sung Hwa Hong, MD, PhD \\ Department of Otorhinolaryngology- \\ Head and Neck Surgery, \\ Sungkyunkwan University \\ School of Medicine, \\ Samsung Changwon Hospital, \\ 158 Paryong-ro, Masanhoewon-gu, \\ Changwon 51353, Korea \\ Tel $+82-55-233-8000$ \\ Fax $+82-55-233-8004$ \\ E-mail hongsh@skku.edu
}

Background and Objectives The purpose of this study was to figure out the clinical effectiveness of the bluetooth wireless streaming when used with a hearing aid during cell phone conversation for hearing-impaired listeners.

Subjects and Method Twenty-four adults with hearing loss participated (mild: 3, moderate: 13, moderately severe: 8 ) in the study. The following three objective tests and one subjective questionnaire were administered to all participants; 1) consonant and Monosyllabic test in an noisy environment, 2) speech recognition test in quiet and noisy conditions, 3) listening effort test, and 4) questionnaire about sound quality and preference. Each objective test was conducted in three different cell phone conversation environments as follows; 1) unaided condition, 2) aided condition, with the bluetooth function off, and 3) aided condition, with the bluetooth function on.

Results In the aided condition with the bluetooth function off, performance on consonant and monosyllabic tests was the lowest $(p<0.05)$. However, when the bluetooth function was turned on, the result showed statistically significant superior performance $(p<0.05)$. For the words and sentences test in noisy conditions, using wireless streaming feature with the hearing aids were beneficial compared to not using the feature $(p<0.05)$. However, no significant difference was found between the bluetooth off and on conditions in quiet conditions. Listening effort was significantly lower in noisy background for aided bluetooth on condition $(p<0.05)$. There was no significant difference in sound quality according to each condition, but the preference of Bluetooth feature was overwhelmingly high.

Conclusion Bluetooth wireless streaming is beneficial during phone conversation in noisy environments for users of hearing aids.

Korean J Otorhinolaryngol-Head Neck Surg 2020;63(3):101-7

Key Words Cell phone · Hearing aids · Hearing loss · Smartphone - Wireless Technology.

This is an Open Access article distributed under the terms of the Creative Commons Attribution Non-Commercial License (https:/creativecommons.org/licenses/by-nc/4.0) which permits unrestricted non-commercial use, distribution, and reproduction in any medium, provided the original work is properly cited. 


\section{서 론}

세계 보건 기구(World Health Organization)의 최근 통계 에 의하면 전세계 인구의 $5 \%$ 인 4억 6천 만여 명이 현재 난청 을 호소하고 있으며 2050년에는 9억 명을 초과할 것이라 예 상된다. ${ }^{1)}$ 보청기는 난청 환자들에게 있어서 가장 중요한 청각 재활 수단 중의 하나로 보청기 사용률 또한 해마다 증가하고 있는 추세이다. ${ }^{2)}$ 이러한 보청기를 통한 청각의 재활과 의사 소통의 향상은 근본적으로 사회적 관계에 매우 중요하며 이 는 삶의 질에 직접적인 영향을 미친다. ${ }^{3)}$

일반적으로 보청기 만족도는 주변 청취 환경에 따라 많은 차이가 있으며, 다양한 청취 환경에서 대화가 가능할 때 보 청기 구매자의 만족도는 극대화될 수 있다. ${ }^{4)}$ 2009년에 발표 된 MarkeTrak VIII연구에 의하면 전화 통화가 보청기 사용 자들이 가장 중요하다고 생각하는 상황 중에 하나로 선택되 었다. ${ }^{5)}$ 이처럼 전화 통화는 의사소통과 사회적 관계 유지의 측면에서 매우 중요하나 난청이 있는 사람들은 가장 어려워 하는 상황 중에 하나로, 특히 배경 소음이 있는 환경에서는 통화가 더욱 어려워, 사회적으로나 직업적인 문제로까지 연결 되기도 한다. ${ }^{6}$

전화 통화가 이처럼 난청 환자들에게 어려운 이유는 시각 정보가 결여되어 있는 상태에서 음향신호가 실제 대화 상황 보다 훨씬 떨어짐과 동시에 대역폭 또한 $0.3 \sim 3.5 \mathrm{kHz}$ 범위로 제한되어 있기 때문이다. 이 상태에 배경 소음까지 존재할 경 우 더욱 문장 및 단어에 대한 인지능력이 떨어져 주변 소음을 차단하는 것이 통화 상황에서는 매우 중요하다.) 특히 보청기 착용자들의 경우 보청기를 빼지 않고는 수화기를 보청기의 마이크 주변에 위치 시키고 통화를 해야 하는데, 정확히 위치 시키기도 어려울 뿐만 아니라 가까이 가져가면 되울림이 발생 하여 통화 자체가 쉽지 않다. ${ }^{8}$ 따라서 이러한 불편함을 해소 하고 신호 대 잡음비를 높여 전화 통화의 품질을 획기적으로 개선시키려는 여러 노력들이 있었으며 그중 하나가 바로 무선 통신 기술이다. 여러 기술 중 최근에 특히 주목받는 것은 블 루투스(bluetooth) 기능이다.

블루투스는 1994년 개발된 저전력 무선통신의 기술로 현재 스마트 휴대전화, 카메라, 스피커, 시계, 자동차 등 우리 일상 생활에 이미 널리 퍼져 있으며 해마다 사용량이 증가하고 있 는 추세이다. ${ }^{9}$ 특히 보청기에 있어서 블루투스의 기술은 스마 트 휴대전화와의 연동과 양이통신을 가능하게 하며 다른 기 술에 비해 전력 소모가 적고 호환성이 매우 뛰어 나다는 장점 이 있다. ${ }^{10)}$ 그럼에도 불구하고, 아직 세계적으로 보청기의 무 선 통신 기술로 블루투스 기능을 활용한 통화 품질의 영향에 대해 체계적으로 분석한 연구는 전무한 상태이다. 따라서 이
번 연구는 난청인들을 대상으로 한 전향적 연구를 통해 다양 한 환경에서 전화 통화 시에 블루투스 기술 활용의 효용성과 효과를 객관적, 주관적으로 분석하고자 한다.

\section{대상 및 방법}

\section{대 상}

2017년 4월 2018년 12월까지 순음청력 검사의 양측의 평 균 청력 역치가 4 분법으로 경도 $(26 \mathrm{~dB} \mathrm{HL})$ 이상인 감각신경 성 난청 환자 총 24 명(남자 13 명, 여자 11 명)이 본 연구에 참여 하였다. 대상자들 중 3명은 경도 난청 $(26 \sim 40 \mathrm{~dB}), 13$ 명은 중 도 난청(41 55 dB), 8명은 중고도 난청 $(56 \sim 70 \mathrm{~dB})$ 을 보였다. 참가자들의 평균나이는 58.0세(20 72세)였으며 양측의 평균 청력 역치는 $50.3 \mathrm{~dB}$ 이었다(Fig. 1). 참가자들 중 14 명은 이전 에 최소한 3개월 이상 보청기를 사용해 본 경험이 있는 유 경 험자였으며 10 명은 사용 경험이 전혀 없었다. 대상자 중 블루 투스 기능을 활용하여 기존에 전화 통화를 해 본 참가자는 단 1명이었다. 본 연구는 '헬싱키 선언(Declaration of Helsin$\mathrm{ki})^{\prime}$ 을 준수하였으며, 삼성서울병원 연구윤리심의위원회의 승 인을 받고 사전에 모든 참가자들에게 충분한 설명 후 동의를 받고 진행하였다(IRB No. 2017-05-130).

\section{방 법}

본격적인 연구 참여에 앞서 난청 정도를 평가하기 위해 이 중 방음 부스에서 순음청력역치와 어음인지역치와 단어인지 도를 평가하였다(Clinical audiometer system Orbiter 922, GSI-61, Grason-Stadler, Eden Prairie, MN, USA). 순음청 력의 결과는 4 분법 $(0.5,1,2,4 \mathrm{k}$ 의 평균)을 기준으로 계산하 였으며 이를 바탕으로 보청기를 적합하였다. 연구에 사용된 보청기는 GN Resound사의 LINX 3D LT961-DRW(RIC type, 17채널, GN Otometrics A/S, Denmark) 제품으로,

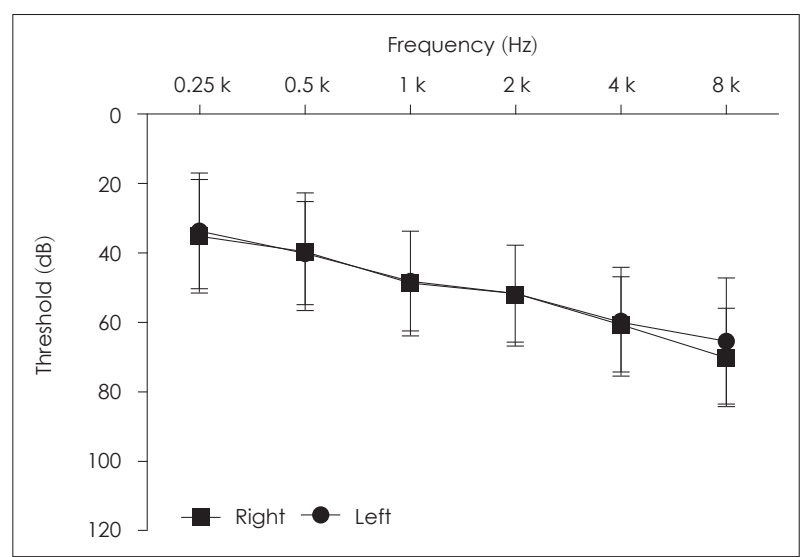

Fig. 1. Average puretone hearing thresholds of all participants. 
1 년 이상의 경험이 풍부한 전문 청각사에 의해 보청기 적합이 NAL-NL2(비선형)를 바탕으로 시행되었으며 양이 개방돔 (open dome)을 적용하였다. 보청기의 기타 알고리즘은 기본 값(전방향성 모드, 주파수 압축기능 및 잡음제거기능 off, 피 드백 제거기능 on)으로 설정하였으며 검사 시 보청기와 휴대 폰의 볼륨은 개인의 쾌적 레벨로 설정하였다. 휴대폰은 삼성 Galaxy S7(모델명: SM-G930SZKASKO, Samsung Electronics, Suwon, Korea)을 사용하였다.

연구는 다음과 같은 3 가지의 객관적 검사와 1 가지의 주관 적 설문으로 구성되었다; 1) 자음 및 단음절 인지 검사(consonant and monosyllabic test), 2) 문장 인지 검사(speech recognition test), 3) 듣기노력 검사(listening effort test), 4) 음질 및 선호도 관련 설문이 시행되었다. 각각의 객관적 검사 는 다음과 같이 3 가지 다른 환경에서 진행되었고 순서는 무 작위로 진행되어 검사 해석의 신뢰도를 높였다; 1) 보청기 비 착용 상태, 2) 양이 보청기를 착용하였으나 블루투스 기능은 사용하지 않고 직접 보청기 가까이 휴대폰을 위치시키고 통 화하는 상태, 3) 양이 보청기 착용 상태에서 무선 통신 기술 인 블루투스 기능을 활용하여 통화하는 상태. 모든 검사 조 건 중 제시된 소음은 다중 말소리 잡음(multi-talker babble noise)을 $75 \mathrm{dBA}$ 의 강도로 제시하였다.

자음 검사의 경우 각각 $75 \mathrm{dBA}$ 의 소음 환경에서 무의미한 2음절(예; '아라', ‘아바', ‘아마', '아다') 단어를 듣고 모니터상에 서 해당되는 정답을 선택하는 형태로, 단음절 검사 역시 동일 한 조건에서 단음절 단어를 듣고 해당 단어를 따라 말하는 형 식으로 진행되었다. 문장인지 검사의 경우 조용한 환경(quiet)과 $75 \mathrm{dBA}$ 소음 환경에서 각각 진행되었으며 문장은 $\mathrm{Ko}^{-}$ rean-Central Institute for the Deaf(K-CID)와 Korean Hearing in Noise Test $(\mathrm{K}-\mathrm{HINT})$ 문장을 사용하여 검사자가 전 화상으로 말한 문장을 듣고 따라 말하며 어음인지 능력을 확 인하였다. 단어는 총 40점 만점, 문장은 10 점이 만점이었다. 듣기노력 검사 또한 동일한 소음 환경에서 Korean Speech Intelligibility in Noise(K-SPIN) 문장을 전화로 듣고 대답하 는 형태로 검사 종료 후 주관적인 듣기 노력 정도를 대상자 스스로 점수화하여 평가하였다. 주관적 평가로 음질에 대한 결과는 무소음 환경에서 전화를 이용하여 동일한 말소리를 각각의 조건에서 들려준 후 음질에 대한 점수를 대상자가 스 스로 점수화하였으며(100점 만점, 5점 간격으로 배점), 이후 가장 선호하는 조건을 고르도록 하였다.

\section{통계 분석}

통계 분석 방법은 정규성 검정을 실행하였을 때, 정규성 만족이 충족되지 않아 비모수 검정(nonparametric analysis)
을 시행하였다. 세 가지 조건(보청기 미착용, 보청기 착용 후 블 루투스 미사용, 보청기 착용 후 블루투스 사용)에 따라 Friedman test를 사용하여 세 가지 조건을 비교하였으며, 사후 분 석으로 Wilcoxon signed rank test를 이용하여 두 가지 조건 을 각각 비교하였다. 사후 분석 비교 결과는 multiple comparison에 의한 type I error 증가를 Bonferroni correction meth$\mathrm{od}$ 를 이용하여 모두 보정하였다. 모든 분석에서는 양측검정 을 실시하였고, 유의 수준 0.05 를 기준으로 통계적 유의성을 확인하였다. Median $(\mathrm{Q} 1, \mathrm{Q} 3)$ 값은 소수점 첫째 자리까지, $p^{-}$ value는 소수점 넷째 자리까지 반올림하여 표기하였다.

\section{결 과}

\section{자음 및 단음절 검사(Consonant and monosyllabic test)}

$75 \mathrm{dBA}$ 의 다중 말소리 잡음 환경하에서 휴대전화를 이용 한 자음 및 단음절 검사를 시행하였고 정답률을 분석하였다 (Fig. 2). 자음 검사의 경우 보청기 미착용 시 중간값 25.9[inter-quartile range(IQR), 14.8 40.7]를 보였으며, 보청기를 착용 후 블루투스 기능을 활용하지 않은 상태에서는 중간값 13.0(IQR, 7.4 24.1)으로 가장 낮은 정답률을 보였고 블루투 스 기능을 사용하면 중간값 38.9(IQR, 27.8 50.0)로 가장 우 수한 결과를 보였고 각 조건에 따른 정답률의 차이는 모두 통계적으로 유의하였다 $(p<0.05)$. 단음절 검사 역시 보청기 미착용 상태에서 중간값이 45.0(IQR, 25.0 55.0)이었으나, 보 청기 착용 후 블루투스를 사용하지 않았을 때에는 중간값이 25.0(IQR 10.0 35.0)으로 통계적으로 유의하게 떨어졌지만 $(p<0.05)$, 블루투스 기능 사용 시 중간값 50.0(40.0 60.0)으 로 가장 높은 정답률을 보였다.

\section{문장인지 검사(Speech recognition test)}

무소음 및 소음 환경에서 전화 통화상의 문장 인지능력을 평가하였다. 문장 속에서 단어와 문장의 정답률을 분석하였 으며, 조용한 환경에서 단어 및 문장의 점수는 세 조건의 결 과가 모두 비슷하였으나, 소음 환경에서는 통계적으로 유의한 차이를 보였다(Fig. 3). 소음 환경에서 단어의 경우 보청기 비 착용 상태에서 중간값 36.5(IQR, 34.0 40.0), 블루투스 미사 용 상태는 32.0(IQR, 20.0 35.0)으로 통계적으로 유의하게 점수가 낮았으며 $(p<0.001)$ 블루투스 기능 사용 시 38.5(IQR, 35.0 39.0)으로 가장 높은 점수를 보였으며 문장 검사도 이 와 유사한 결과를 보여, 조용한 환경에서는 조건별 큰 차이가 없었지만 소음 속에서는 보청기 착용 상태에서 블루투스 기 능을 활용한 결과가 가장 우수하였다. 


\section{듣기노력 검사(Listening effort test)}

$75 \mathrm{dBA}$ 의 소음 환경 속에서 얼마나 듣기 위해 집중을 하였 는지 듣기 노력 검사를 시행하였으며, 10 개의 문항에 대한 정 답률(Fig. 4A)과 주관적 듣기노력(Fig. 4B)을 분석하였다. 정
답률의 경우 보청기 미착용 시 중간값 5.5(IQR, 1.0 8.0)를 보 였으나 보청기를 착용했으나 블루투스 기능을 활용하지 않았 을 경우 2.0(IQR, 0.0 7.0)으로 낮아졌으며, 블루투스 기능을 사용하였을 때의 평균이 7.0(IQR, 5.0 8.0)으로 가장 높았고
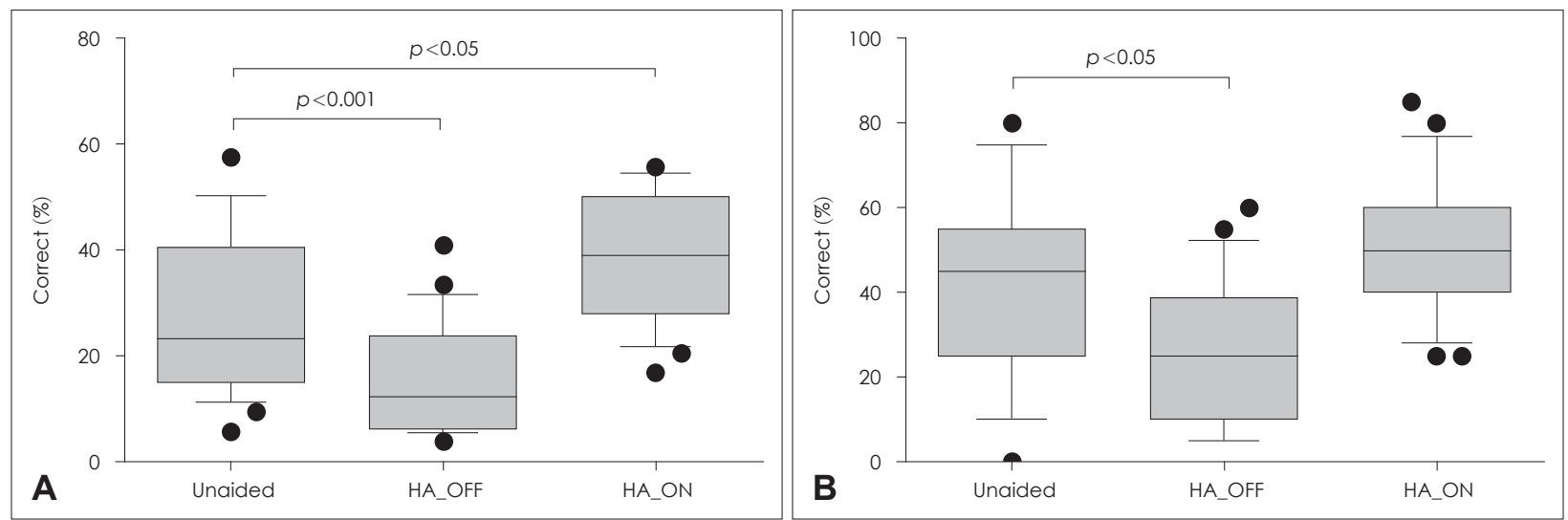

Fig. 2. Correction rate (\%) of consonant (A) and monosyllabic (B) tests. Unaided, participants listen to phone calls without wearing hearing aids. The horizontal lines within the bars represent the median values; bars, interquartile ranges; the error whiskers, the highest and lowest points; and the circle is an outlier. Statistically significant differences are indicated with an asterisk. HA_OFF: listening to phone calls through hearing aids microphones, HA_ON: listening to phone calls using the bluetooth function of the hearing aids.

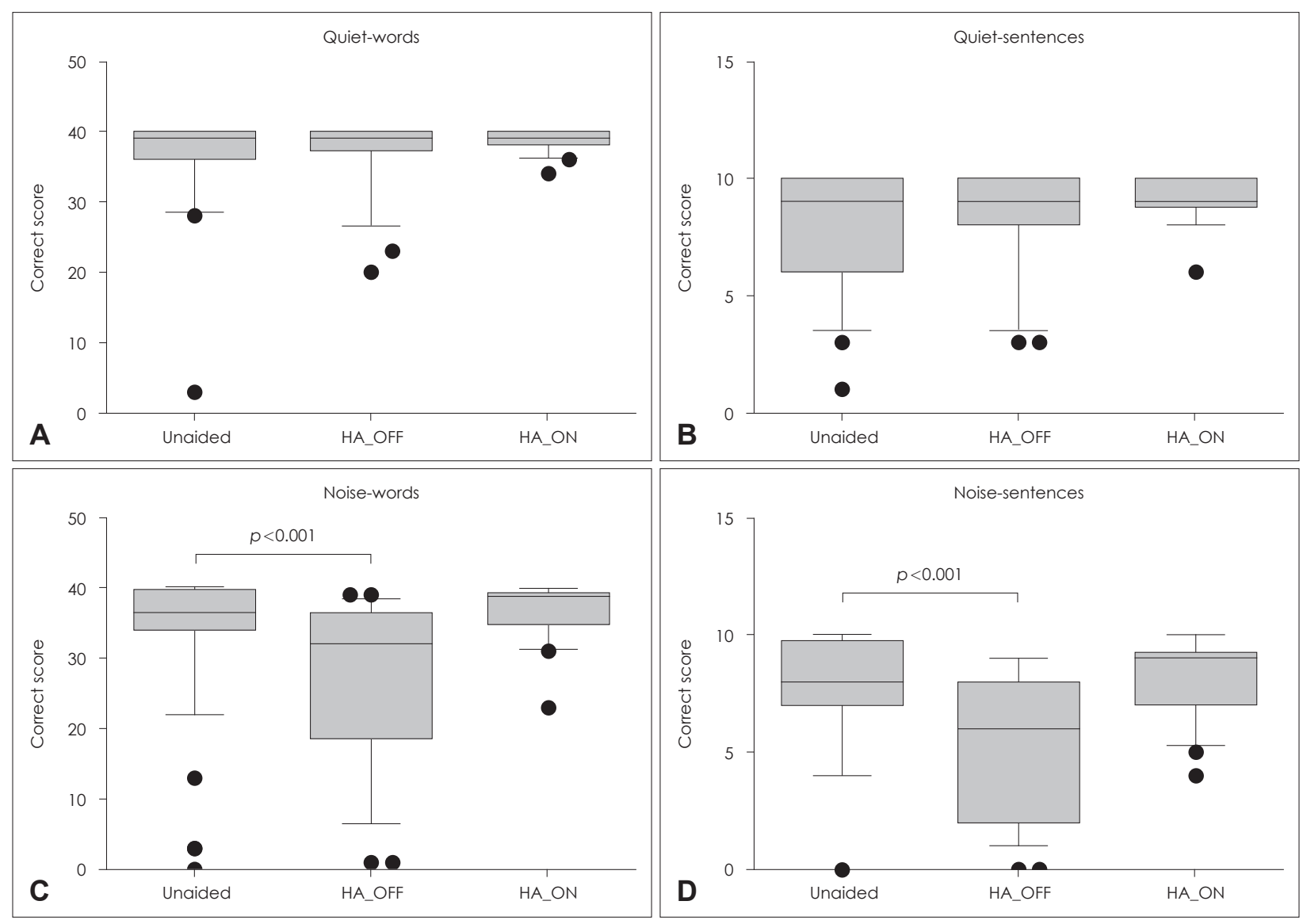

Fig. 3. Correction score of sentences and words tests in quiet ( $A$ and $B)$ and noise ( $C$ and $D)$ environments. Unaided, participants listen to phone calls without wearing hearing aids. The horizontal lines within the bars represent the median values; bars, interquartile ranges; the error whiskers, the highest and lowest points; and the circle is an outlier. Statistically significant differences are indicated with an asterisk. HA_OFF: listening to phone calls through hearing aids microphones, HA_ON: listening to phone calls using the bluetooth function of the hearing aids. 
이는 통계적으로 유의하였다 $(p=0.017)$. 검사 종료 후 주관적 듣기노력을 설문을 통해 평가하였으며 보청기 미착용 시 85.0(IQR, 65.0 95.0)점을 보이던 듣기노력이 보청기를 착용 하였으나 블루투스 기능을 사용하지 않으면 90.0(IQR, 75.0 95.0)으로 상승하여 듣기노력이 오히려 보청기 착용 전 에 비해 통계적으로 유의미하게 상승하였음을 확인하였다 $(p=0.012)$

\section{음질 및 선호도의 설문조사(Sound quality and preference questionnaire)}

무소음 환경에서 동일한 말소리를 듣고 음질을 평가한 결 과 음질에 대한 점수는 각 조건별로 유의한 차이가 없었다 (Fig. 5A). 선호도의 경우에는 보청기 착용 상태에서 블루투 스 기능을 활용하여 통화하는 조건의 선호도가 가장 높았으
며(79.2\%), 보청기를 착용하였으나 블루투스 기능을 사용하지 않는 조건을 선호했던 응답자는 단 한 명도 없었다(Fig. 5B).

\section{고 찰}

보청기를 착용한 상태에서 전화 통화를 하는 것은 쉬운 일 이 아니다. 한 연구 결과에 따르면 숙련된 보청기 사용자의 $75 \%$ 이상이 보청기로 전화를 통화하는 데 있어서 적절하고 필요한 조치를 취할 수 없었다고 밝혔다. ${ }^{11)}$ 이 상황에서 가장 문제되는 것은 되울림(feedback)과 주변 소음으로, 이 두 가 지가 보청기 사용자의 전화 통화의 만족도를 떨어뜨리는 주 요 원인으로 여겨지고 있다. ${ }^{12)}$ 이러한 문제점은 휴대전화와 관 련된 급속한 기술의 발전에도 불구하고 쉽게 해결되지 못하 고 있다. 특히, 주변 소음이 심할수록 보청기 사용자들은 휴
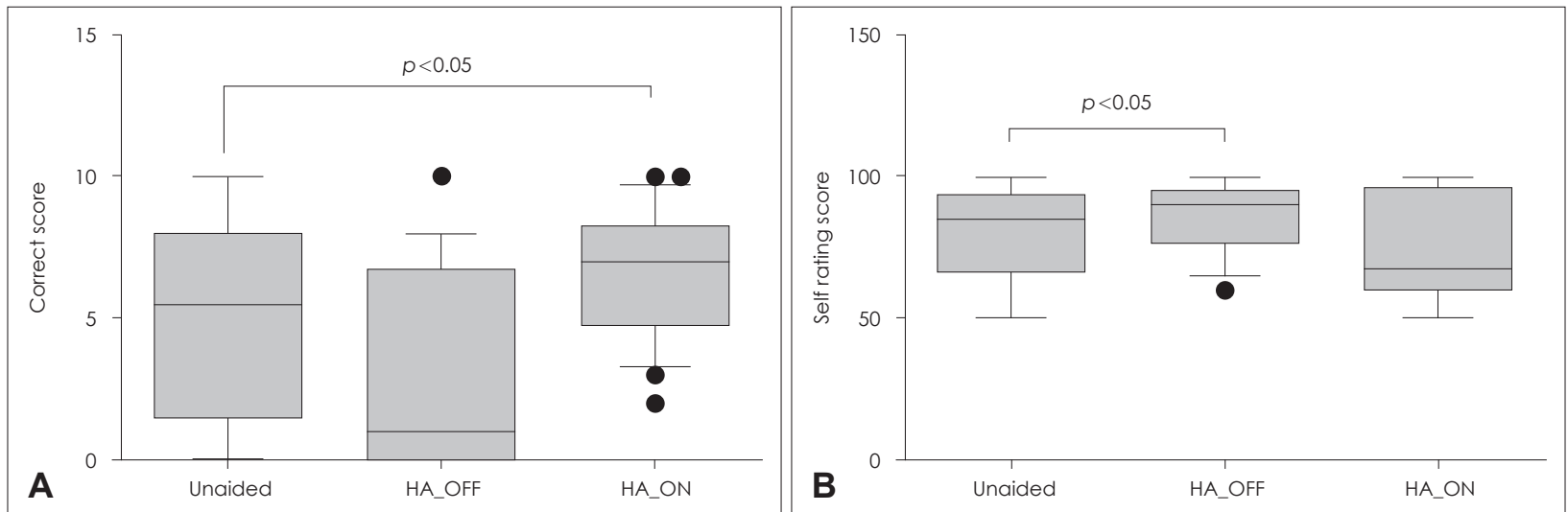

Fig. 4. Score of correct answer in listening effort test (A) and self-rating score about listening effort (B). Unaided, participants listen to phone calls without wearing hearing aids. The horizontal lines within the bars represent the median values; bars, interquartile ranges; the error whiskers, the highest and lowest points; and the circle is an outlier. Statistically significant differences are indicated with an asterisk. HA_OFF: listening to phone calls through hearing aids microphones, HA_ON: listening to phone calls using the bluetooth function of the hearing aids.
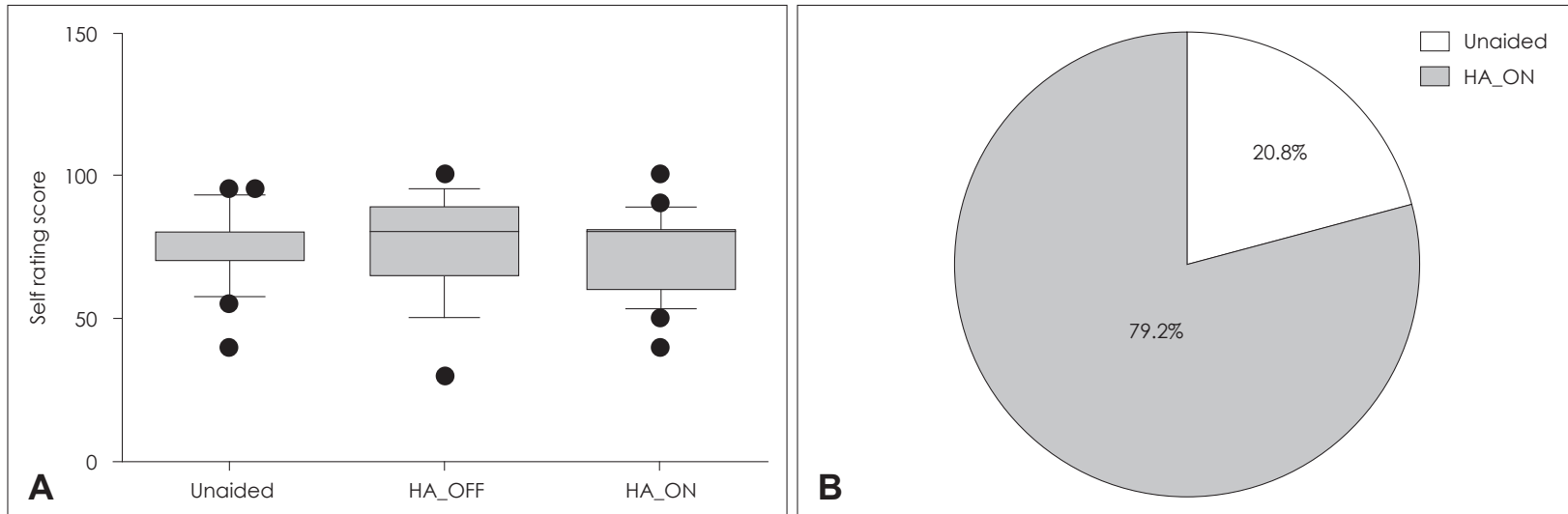

Fig. 5. Survey results for each condition. Self-rating score about sound quality (A) and results of all participants' preference by condition (B). Unaided, participants listen to phone calls without wearing hearing aids. The horizontal lines within the bars represent the median values; bars, interquartile ranges; the error whiskers, the highest and lowest points; and the circle is an outlier. Statistically significant differences are indicated with an asterisk. HA OFF: listening to phone calls through hearing aids microphones, HA ON: listening to phone calls using the bluetooth function of the hearing aids. 
대전화의 수화기를 보청기의 마이크에 가까이 가져가야 하지 만 이는 필연적으로 되울림을 증가시킬 수밖에 없어 만족도 를 떨어뜨린다. ${ }^{13)}$ 비록 보청기에서 피드백 방지 알고리즘의 상당한 발전이 있었지만, 난청 정도가 심해 충분한 이득이 필요한 환자에서 이러한 문제의 개선은 쉽지 않았다. ${ }^{14,15)}$

이러한 문제점을 복합적으로 해결할 수 있는 기술이 바로 무선 통신 기술이다. 그동안 보청기나 인공와우의 사용에 있 어서 telecoil 및 FM 시스템에 대한 다양한 연구와 분석이 있었다. ${ }^{16)}$ 하지만 기본적으로 telecoil은 장비가 설치된 곳에 서만 작동이 가능하여 공간적인 제약이 따르며 FM 시스템은 연결이나 호환성 면에서 블루투스 기술보다는 편의성이나 호 환성이 떨어진다. ${ }^{13)}$ 블루투스는 현재 대부분의 휴대전화에 기 본적으로 탑재된 기술로 보청기나 휴대전화의 종류에 상관없 이 호환되며, 전력의 소비가 적고, 별도의 추가적인 작동이 필 요없이 블루투스 기능의 활성화만으로도 연결이 가능하여 매 우 편리하다. 블루투스의 시장은 전세계적으로 급격히 증가 중에 있으며, 향후 대부분의 보청기에서 기본적으로 사용이 가능할 것으로 보인다. ${ }^{10)}$

이번 연구에서는 다양한 검사를 통해 난청 환자들에 있어 서 보청기의 블루투스를 활용한 전화 통화의 유용성에 대해 검증하고자 하였다. 조용한 환경에서는 문장이나 단어 검사 등에서 블루투스의 활용이 통계적 차이를 보이지는 못하였지 만, 소음 환경에서는 블루투스 기능을 사용하였을 때 자음 검사 및 듣기노력 검사에서 우수한 결과들을 보였으며 통계 적으로도 유의하였다. 실제 설문조사에서도 $80 \%$ 에 가까운 대상자들이 블루투스 기능을 사용한 통화 환경을 가장 선호 하는 것으로 조사되었다. 반면 보청기를 착용하였으나 블루 투스 기능을 활용하지 않았을 경우에는 오히려 보청기를 착 용하지 않았을 때보다 모든 객관적 검사의 수치가 떨어졌다. 전체 참가자들 중 $58.3 \%$ 에 달하는 참가자들이 이미 3 개월 이 상 보청기를 사용해 본 유경험자로 평균 보청기 사용 경험이 37.5 개월이나 되었으나 그 누구도 보청기를 착용하였으나 블 루투스 기능을 사용하지 않은 통화 환경을 선호하지 않았다. 이는 보청기의 사용법에 충분히 익숙해져 있다고 하더라도 수화기를 보청기에 직접 가져다 대고 통화하는 데 상당한 제 약이 있음을 시사하는 결과이다. 그 이유로는 휴대전화를 보 청기에 가까이 위치하면서 발생하는 피드백과 주변 소음에 비해 휴대전화의 수신음이 상대적으로 작고 명확하지 않고 보청기가 소음 상황에서 휴대전화 수신음만 특이적으로 증폭 시키지 못한다는 점이 주요 원인으로 생각된다.

검사자의 질문을 전화로 듣고 대답하면서 환자 개인별 듣 기노력을 평가하였고, 보청기 착용 후 블루투스 기능을 활용 하였을 때 통계적으로 유의하게 점수가 높았다. 동시에 주관
적인 듣기노력 정도는 보청기를 착용하였지만 블루투스 기능 을 사용하지 않았을 때가 가장 높은 것으로 평가되어 이는, 앞서 시행된 소음 속 전화 통화 능력의 결과와 일치하는 것으 로 나타났다. 따라서, 단순히 보청기를 착용한 상태에서 블루 투스 기능 없이 전화 통화를 하는 것은 듣기 능력을 저하시킬 뿐만 아니라, 과도한 듣기노력을 사용하게 만들어 장시간 통 화 시 쉽게 피로를 느끼게 만들 수도 있다.

이번 연구에 사용된 보청기는 GN-ReSound사의 LINX 3D 제품으로 전화 통화 시 수화음이 양이의 보청기로 동시에 전 달이 된다. 이러한 점은 소음 환경하에서 통화 시 큰 이점으 로 작용할 수 있는데, Picou와 Ricketts ${ }^{17)}$ 의 연구에 의하면 블루투스 기능을 활용하여 한쪽으로 신호를 주었을 때 보다 양측으로 신호를 주었을 때 훨씬 좋은 신호 대 잡음비를 보 여주었다. 다만 이 연구에서는 보청기를 폐쇄돔(occluding dome)을 사용하였을 때만 효과가 있었다고 언급하고 있으나, 저자들의 이번 연구에서는 개방돔(open dome)을 사용하였 음에도 불구하고 뚜렷한 효과를 보여주었다. 이는 2011년에 발표된 당시 연구 결과보다 보청기의 잡음제거 기능이나, 음 질 등 여러 측면에서의 많은 기술적 발전이 주요한 이유라고 판단된다.

본 연구의 제한점으로는 단일 회사의 단일 제품만을 대상 으로 평가하여 모든 보청기에 대해 일반화시켜 해석하기에는 무리가 있으며, 연구 참여 대상자가 총 24명으로 숫자가 많지 않다는 점 그리고, 연구실 환경에서 1 회의 실험 및 평가만으 로 효과를 분석하고 선호도에 대한 설문을 진행하여 적응 및 사용 기간에 대한 요소가 고려되지 못했다는 점이다. 따라서 향후에는 여러 제품들을 대상으로 다양한 청력의 환자군을 모집하여 실험실 환경에서 분석한 후 실제 일상생활에서 전 화 통화 시 정해진 방법들을 사용하도록 안내한 뒤에 만족도 나 선호도를 종합하여 분석하는 연구가 진행되어야 할 것으 로 보인다.

\section{Author Contribution}

Conceptualization: Young Sang Cho, Il Joon Moon, Sung Hwa Hong. Data curation: Young Sang Cho, Soo Jin Kang. Formal analysis: Ji Hyun Lim. Methodology: Soo Jin Kang, Si Hyung Kang. Project administration: Sung Hwa Hong. Supervision: Il Joon Moon, Sung Hwa Hong. Writing — original draft: Young Sang Cho. Writing — review \& editing: Ji Won Seo, Sung Hwa Hong.

\section{ORCIDs}

Sung Hwa Hong https://orcid.org/0000-0001-6906-8925 Young Sang Cho https://orcid.org/0000-0002-4040-7206

\section{REFERENCES}

1) World Health Organization. Deafness and hearing loss [online] 2019 Mar 20 [cited 2019 Jun 10]. Available from: URL: http:// 
www.who.int/en/news-room/fact-sheets/detail/deafness-andhearing-loss.

2) Kochkin S. MarkeTrak VIII: 25-Year trends in the hearing health market. Hear Rev 2009;16(11):12-31.

3) Weinstein BE. Hearing aid satisfaction revisited. Hear J 2016;69(5): 26-30.

4) Kochkin S. Increasing hearing aid adoption through multiple environmental listening utility. Hear J 2007;60(11):28-31.

5) Kochkin S. MarkeTrak VIII: Consumer satisfaction with hearing aids is slowly increasing. Hear J 2010;63(1):19-27.

6) Au A, Blakeley JM, Dowell RC, Rance G. Wireless binaural hearing aid technology for telephone use and listening in wind noise. Int J Audiol 2019;58(4):193-9.

7) Drullman R, Bronkhorst AW. Speech perception and talker segregation: Effects of level, pitch, and tactile support with multiple simultaneous talkers. J Acoust Soc Am 2004;116(5):3090-8.

8) Picou EM, Ricketts TA. Efficacy of hearing-aid based telephone strategies for listeners with moderate-to-severe hearing loss. J Am Acad Audiol 2013;24(1):59-70.

9) Wang H. Overview of Bluetooth technology. State College, PA: Department of Electrical Engineering, Pennsylvania State University; 2001

10) Edwards B. The future of hearing aid technology. Trends Amplif
2007;11(1):31-45.

11) Desjardins JL, Doherty KA. Do experienced hearing aid users know how to use their hearing AIDS correctly? Am J Audiol 2009;18(1): 69-76.

12) Smith GM. The Telephone adapter and other telephone aids for the hard of hearing. Volta Rev 1974;76(8):474-84.

13) Kim MB, Chung WH, Choi J, Hong SH, Cho YS, Park G, et al. Effect of a bluetooth-implemented hearing aid on speech recognition performance: Subjective and objective measurement. Ann Otol Rhinol Laryngol 2014;123(6):395-401.

14) Chung K. Challenges and recent developments in hearing aids. Part I. Speech understanding in noise, microphone technologies and noise reduction algorithms. Trends Amplif 2004;8(3):83-124.

15) Latzel M, Gebhart TM, Kiessling J. Benefit of a digital feedback suppression system for acoustical telephone communication. Scand Audiol Suppl 2001;(52):69-72.

16) Schafer EC, Romine D, Musgrave E, Momin S, Huynh C. Electromagnetic versus electrical coupling of personal frequency modulation (FM) receivers to cochlear implant sound processors. $\mathrm{J}$ Am Acad Audiol 2013;24(10):927-40.

17) Picou EM, Ricketts TA. Comparison of wireless and acoustic hearing aid-based telephone listening strategies. Ear Hear 2011;32(2):209-20. 